IRSTI 81.93 .29

DOI: https://doi.org/10.26577/JMMCS.2021.v112.i4.13

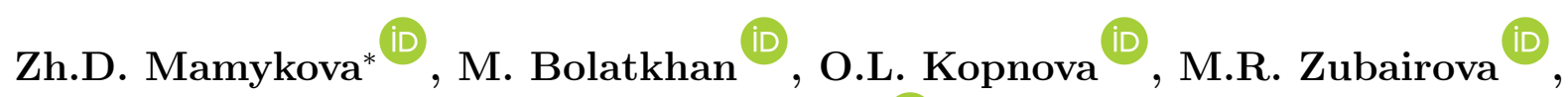 \\ Sh.Zh. Rabat \\ al-Farabi Kazakh National University, Kazakhstan, Almaty \\ E-mail: *Zhanl.Mamykova@kaznu.edu.kz
}

\title{
DEVELOPMENT OF THE INFORMATION AND ANALYTICAL SYSTEM OF THE UNIVERSITY
}

Today, the introduction of analytical systems into the university management circuit has become a necessary and priority task of higher educational institutions. It was led by the desire of the university management to understand the nature of data to improve the quality of educational services and decision-making. This article discusses the analysis of information systems, comparison of business intelligence platforms, and approaches to designing information and analytical system within the university as one of the key elements of the university's information infrastructure.

The presented work describes the data architecture of the corporate information systems of alFarabi Kazakh National University, designing and implementing an information and analytical system at the university and on the Microsoft Power BI cloud business analysis platform. This system integrates all the disparate data of the university's corporate information systems and transactional data sources. Furthermore, the logic of data extraction, transformation, implementation of visual reporting in Power BI, and the model of role-based access to them are also described.

Key words: data, information and analytical system, visualization, data management, university.

\section{Ж.Д. Мамыкова*, М. Болатхан, О.Л. Копнова, М.Р. Зубаирова, Ш.Ж. Рабат әл-Фараби атындағы Қазақ ұлттық университеті, Қазақстан, Алматы қ., E-mail: Zhanl.Mamykova@kaznu.edu.kz \\ Университеттің ақпараттық-талдау жүйесін әзірлеу}

Бүгінгі таңда университетті басқару контурына аналитикалық жүйелерді енгізу жоғары оқу орындарының қажетті және басым міндеті болып табылады. Бұан университет басшылығының білім беру қызметтерінің сапасын жақсарту және шешім қабылдау мақсатында деректердің табиғатын түсінуге деген ұмтылысы себеп болды. Бұл мақалада ақпараттық жүйелерді талдау, бизнес-талдау платформаларын салыстыру және университеттің ақпараттық инфрақұрылымының негізгі элементтерінің бірі ретінде университет ішіндегі ақпараттықаналитикалық жүйені жобалау тәсілдері қарастырылады.

Ұсынылған жұмыста Қазақ ұлттық университетінің корпоративтік ақпараттық жүйелерінің архитектурасы, ақпараттық-талдау жүйесін Microsoft Power BI бизнес-талдаудың бұлтты платформасында жобалау және іске асыру тәсілі сипатталған. Бұл жүйе университеттің корпоративтік ақпараттық жүйелері мен транзакциялық деректер көздерінің барлық шашыраңқы деректерін біріктіреді. Сондай-ақ, деректерді алу, түрлендіру, Power BI қолдана отырып, визуалды есеп беру нысанын енгізу логикасы және оларға рөлдік қол жетімділік моделі келтірілген.

Түйін сөздер:деректер, ақпараттық-аналитикалық жүйе, визуализация, деректерді басқару, университет.

Ж.Д. Мамыкова*, М. Болатхан, О.Л. Копнова, М.Р. Зубаирова, Ш.Ж. Рабат

Казахский национальный университет имени аль-Фараби, Казахстан, г.Алматы

E-mail: Zhanl.Mamykova@kaznu.edu.kz

Разработка информационно-аналитической системы университета 
Сегодня внедрение аналитических систем в контур управления университетом стало необходимой и приоритетной задачей высших учебных заведений. K этому привело желание руководства университета понимать природу данных, с целью совершенствования качества образовательных услуг и принятия решений. В данной статье рассматривается анализ информационных систем, сравнение платформ бизнес-аналитики и подходы проектирования информационно-аналитической системы внутри университета, как один из ключевых элементов информационной инфраструктуры ВУЗа.

В представленной работе описана архитектура данных корпоративных информационных систем Казахского Национального университета им. аль-Фараби, подход проектирования и реализации информационно-аналитической системы в ВУЗе, на облачной платформе бизнесанализа Microsoft Power BI. Данная система интегрирует все разрозненные данные корпоративных информационных систем университета и транзакционных источников данных. Также изложена логика извлечения, преобразования данных, реализация формы визуальной отчетности в Power BI и модель ролевого доступа к ним.

Ключевые слова: данные, информационно-аналитическая система, визуализация, управление данными, университет.

\section{Introduction}

The manager needs to operate with all data flows in the information space of the organization to make managerial decisions. Sources of data for information flows of space are corporate information systems, each of which automates key business processes and, often, does not have consolidated data. There is a need for a qualitative improvement of information and analytical support in educational institutions, including educational processes at all levels.

The complex task of managing a university, according to the authors, is to improve the quality of the scientific and educational process, which requires a systematic and timely analysis of comprehensive and reliable information about the state of the university's activities for decision-making. The solution to this problem is possible by introducing modern information technologies into the management process of the university and constantly improving them. Therefore, higher educational institutions are constantly looking for effective ways to manage scientific and educa-tional activities (GCD) in connection with the university's information infrastructure being developed.

Information infrastructure is a set of solutions of its own and local developments and forms the information space of the university. The information and analytical system (IAS) is a modern, highly effective tool to support the adoption of strategic, tactical, and operational management decisions based on the visual and prompt provision of the entire necessary set of data to users respon-sible for analyzing the state of affairs and making management decisions. The main purpose of the IAS is the dynamic presentation and multidimensional analysis of historical and current data, trend analysis, modeling, and forecasting of the results of various management decisions.

The purpose of developing an IAS in the contour of a corporate information system (CIS) on the example of the al-Farabi Kazakh National University: to create an aggregating system for extracting data from various sources of CIS, transforming them, and uploading them to storage in order to build an operational and intelligent data analysis for their effective perception by consumers. For the implementation of IAS, methods and models were used, such as programming technologies, design of information systems, database theory, statistics, data mining.

The complexity of information and analytical systems affects the entire management 
vertical of the university: corporate reporting, financial and economic planning, and strategic planning. An information-analytical system is a platform in which databases (MS SQL, MySQL, etc.) of disparate information systems of an organization's information infrastructure and transactional data sources are integrated. This data integration accumulates at the cloud storage layer. The cloud architecture of the platform allows you to connect various intelligent data mining services like Microsoft Azure Learning, Analysis Services, and Google Analytics for the building purpose.

Using a systematic approach and applying methods and models of economic and mathematical modeling and data mining, it is possible to build visualization services and predictive analytics. With the Power BI service, you can securely publish reports to your organization and set up automatic data refresh to keep all users up to date. The implementation of the IAS will help in the implementation of such tasks at the university as increasing the efficiency of university management and the processes of scientific and educational activities (GCD); improving the quality of educa-tion; assistance in the tasks of improving the qualifications of teaching staff and the effective use of pedagogical potential; identifying the reasons for academic failure; assessment of the effectiveness of educational and methodological complexes; control of the organization of the educational process.

\section{Literature review}

The analysis of Business Intelligence (BI) systems made it possible to conclude that the Microsoft Power BI platform is the most optimal for the education system since it quickly analyzes a large amount of data. It also allows you to visualize the results of processing an array of data with the ability to personalize; supports the possibility of joint work with data by placing data on an LDAP server; provides secure publication of dashboards and view them from any device with Internet access. In addition, a real-time reporting system enables group work with data and automatic data synchronization for all users.

Power BI is an online service developed by Microsoft for BI, which is a modern, highly effective tool for supporting the adoption of strategic, tactical, and operational management decisions based on the visual and prompt provision of the entire necessary set of data to users responsible for analyzing the state of the organization's activities and making management decisions [3]. Power BI allows you to create adhoc analytic reporting forms that are tailored to the needs of different categories of users and customized visualizations. There is also a mobile Power BI application available on various operating systems for continuous monitoring of the state of affairs and instant response to emergencies. It is also worth noting that Gartner has recognized Microsoft as a leader for fourteen years in a row in the Analysis and BI Platforms nomination in the Gartner Magic Quadrant for 2021 [4].

The implementation of an information and analytical system needs an environment that allows combining data from disparate systems, significantly reducing labor costs for preparing reports and improving the quality of information for strategic decision-making. This function was taken over by BI systems developed on the basis of cloud platforms, which are designed to receive operational information in real-time for making strategic decisions [1]. The following platforms are distinguished for processing and analyzing data and presenting them in the form of reports: Microsoft BI; Oracle BI; SAP Business Objects; QlikView; Qlik Sense; etc. табл. 1 compares the functionality of Qlik, Tableau, and Power BI. 
Table 1. Comparison of Quik, Tableau and Power BI functionality.

\begin{tabular}{|c|c|c|c|}
\hline & Qlick & Tableau & Power BI \\
\hline 胥. & $\begin{array}{l}\text { Qlik is a paid software } \\
\text { that costs } \$ 30 \text { per user } \\
\text { per month, with different } \\
\text { offers for corporate } \\
\text { clients. You can also get } \\
\text { a free trial period for } \\
\text { using the program. For } \\
\text { self-study, there is a free } \\
\text { introductory course on } \\
\text { their official website. }\end{array}$ & $\begin{array}{l}\text { Tableau is also a } \$ 70 \\
\text { per user/month paid } \\
\text { software, with different } \\
\text { offers for corporate } \\
\text { clients. You can also } \\
\text { get a free trial period } \\
\text { for using the program. } \\
\text { For self-study, there are } \\
\text { training videos on their } \\
\text { official website. There is } \\
\text { an adapta-tion of reports } \\
\text { for different forms of } \\
\text { presentation (you can } \\
\text { download and print in } \\
\text {.pdf format). }\end{array}$ & $\begin{array}{l}\text { There are three versions } \\
\text { of Power BI: Basic (free), } \\
\text { Pro ( } \$ 9.99 \text { per user), and } \\
\text { Premium ( } \$ 20 \text { per user } \\
\text { and } \$ 4,995 \text { per capacity } \\
\text { (i.e., all employees in the } \\
\text { organization)). Complete } \\
\text { documentation of the } \\
\text { product's features and } \\
\text { functions is published } \\
\text { on the official website. } \\
\text { There is an adaptation } \\
\text { of reports for different } \\
\text { presentation forms (you } \\
\text { can download and print } \\
\text { in .pdf, .pptx formats, } \\
\text { export tables / reports to } \\
\text { Excel, CSV files). }\end{array}$ \\
\hline$\stackrel{\text { P }}{\exists}$ & $\begin{array}{l}\text { Qlik has its data } \\
\text { processor, which allows } \\
\text { you to use "unprepared" } \\
\text { data and transform it } \\
\text { during loading. }\end{array}$ & $\begin{array}{l}\text { Tableau allows you } \\
\text { to combine several } \\
\text { tables, get rid of empty } \\
\text { or unwanted values, } \\
\text { add calculated fields } \\
\text { (amounts, number, and } \\
\text { average). }\end{array}$ & $\begin{array}{l}\text { Power BI fully } \\
\text { implements internal } \\
\text { ETL, which allows you } \\
\text { to import, transform, } \\
\text { and download data. }\end{array}$ \\
\hline 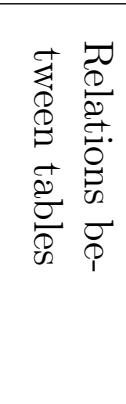 & $\begin{array}{l}\text { Qlik creates keys between } \\
\text { tables based on common } \\
\text { field names. The Data } \\
\text { Model Viewer gives a } \\
\text { complete understanding } \\
\text { of the loaded tables and } \\
\text { the relationship structure } \\
\text { between them. }\end{array}$ & $\begin{array}{l}\text { In Tableau, by default, } \\
\text { the link is also built } \\
\text { by fields with the same } \\
\text { names, but this can also } \\
\text { be edited in the section } \\
\text { "Editing links." }\end{array}$ & $\begin{array}{l}\text { In Power } \\
\text { relationships between } \\
\text { tables are built by } \\
\text { default by fields with the } \\
\text { same names; you can also } \\
\text { edit, de-lete, or create } \\
\text { new relationships in the } \\
\text { "Data Model" section. }\end{array}$ \\
\hline
\end{tabular}




\begin{tabular}{|c|c|c|c|}
\hline 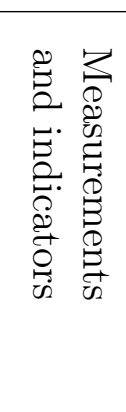 & $\begin{array}{l}\text { B In Qlik, the user } \\
\text { initially sees a list } \\
\text { of all loaded fields, } \\
\text { can distribute all the } \\
\text { fields into dimensions } \\
\text { and indicators using } \\
\text { the Master Items } \\
\text { functionality. }\end{array}$ & $\begin{array}{l}\text { Tableau automatically } \\
\text { determines which } \\
\text { fields are dimensions } \\
\text { and indicators in all } \\
\text { loaded tables (string in } \\
\text { dimensions, numeric in } \\
\text { indicators). }\end{array}$ & $\begin{array}{l}\text { With Power BI Desktop, } \\
\text { you can access SSAS } \\
\text { multidimensional } \\
\text { models, com-monly } \\
\text { referred to as SSAS MD.. }\end{array}$ \\
\hline 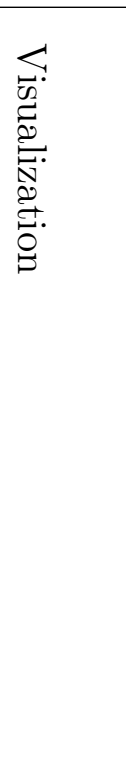 & $\begin{array}{l}\text { Both platforms have } \\
\text { a set of beautiful } \\
\text { charts. Qlik also allows } \\
\text { you to extend your } \\
\text { visualization capabilities } \\
\text { using extensions (ready- } \\
\text { made extensions can } \\
\text { be found on the Qlik } \\
\text { Branch resource or using } \\
\text { open standards such as } \\
\text { HTML5. }\end{array}$ & $\begin{array}{l}\text { Tableau offers a broader } \\
\text { variety of out-of-the- } \\
\text { box visualizations such } \\
\text { as box-and-whiskers, } \\
\text { Bullet-graphs, Gantt } \\
\text { charts. Each chart is } \\
\text { separated into a separate } \\
\text { object, which makes it } \\
\text { easier for the user to } \\
\text { change the presentation } \\
\text { of the diagram (just a } \\
\text { table, a table-heatmap, } \\
\text { a chart with one axis, } \\
\text { a chart with two axes, } \\
\text { etc.). }\end{array}$ & $\begin{array}{l}\text { Power BI has many } \\
\text { visualization libraries } \\
\text { ranging from map } \\
\text { points to nested graphs, } \\
\text { histograms, and more. } \\
\text { There is also a store } \\
\text { of visual elements with } \\
\text { modified visualization } \\
\text { elements. It should be } \\
\text { noted that the user } \\
\text { can create his visual } \\
\text { element and publish } \\
\text { it in this store after } \\
\text { receiving approval from } \\
\text { the creators. }\end{array}$ \\
\hline 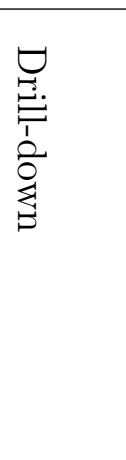 & $\begin{array}{l}\text { In Qlik, to fall into the } \\
\text { lower level, it is necessary } \\
\text { to select one (and only } \\
\text { one) value of the upper } \\
\text { level, after which the } \\
\text { diagram is rebuilt in } \\
\text { the context of the new } \\
\text { dimension. }\end{array}$ & $\begin{array}{l}\text { There is no Dill-down } \\
\text { function in Tableau. } \\
\text { Instead, hierarchies are } \\
\text { created, the user, by } \\
\text { clicking on "+" or "-" } \\
\text { can collapse/expand the } \\
\text { object, that is, work on } \\
\text { the principle of a pivot } \\
\text { table. }\end{array}$ & $\begin{array}{l}\text { In Power BI, you } \\
\text { navigated through } \\
\text { data levels using up and } \\
\text { down arrows. Moreover, } \\
\text { a single arrow shows a } \\
\text { transition to one level, } \\
\text { and a double arrow - } \\
\text { to the lowest level of } \\
\text { hierarchies. }\end{array}$ \\
\hline 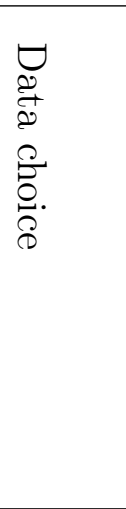 & $\begin{array}{l}\text { In Qlik, the selection } \\
\text { of a value on one } \\
\text { tab / specific object } \\
\text { will be valid for the } \\
\text { entire document - on } \\
\text { all tabs; the selection } \\
\text { will be performed, you } \\
\text { cannot bind a filter to a } \\
\text { particular object. }\end{array}$ & $\begin{array}{l}\text { In Tableau, the opposite } \\
\text { is true. The choice is } \\
\text { made locally - that is, } \\
\text { only to a specific object. } \\
\text { To transfer the selection } \\
\text { between sheets, you need } \\
\text { to configure Actions } \\
\text { on each sheet, which } \\
\text { will select the necessary } \\
\text { values upon activation. }\end{array}$ & $\begin{array}{l}\text { Power BI makes it easy } \\
\text { to combine queries, } \\
\text { create groups and data } \\
\text { selections into a new or } \\
\text { existing table. }\end{array}$ \\
\hline
\end{tabular}




\begin{tabular}{|c|c|c|c|}
\hline 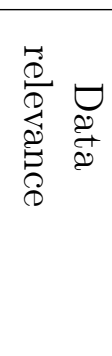 & $\begin{array}{l}\text { Qlik has a configurable } \\
\text { auto-update for } \\
\text { datasets. }\end{array}$ & $\begin{array}{l}\text { Tableau implements } \\
\text { configurable auto-update } \\
\text { of datasets. }\end{array}$ & $\begin{array}{l}\text { There is a configurable } \\
\text { auto-update of datasets } \\
\text { in the cloud version of } \\
\text { Power BI web according } \\
\text { to the established } \\
\text { schedule by configuring } \\
\text { the gateway. }\end{array}$ \\
\hline 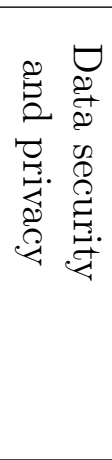 & $\begin{array}{l}\text { Qlik allows } \\
\text { customization of access } \\
\text { by individual data, } \\
\text { users, sheets, streams, } \\
\text { and applications. }\end{array}$ & $\begin{array}{l}\text { Tableau allows you } \\
\text { to customize access } \\
\text { to specific reports, } \\
\text { delineation of rights } \\
\text { for actions in responses } \\
\text { (viewing, } \\
\text { updating, etc.). }\end{array}$ & $\begin{array}{l}\text { Power BI can apply } \\
\text { confidentiality labels to } \\
\text { Power BI data using } \\
\text { Microsoft Information } \\
\text { Protection and customize } \\
\text { roles, functionality, } \\
\text { and access levels for } \\
\text { workspaces, analytic } \\
\text { reports, and datasets. }\end{array}$ \\
\hline 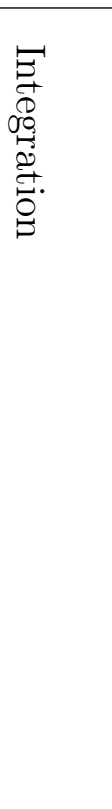 & $\begin{array}{l}\text { Qlik can import data } \\
\text { from Data Warehouses, } \\
\text { Relational Data-bases, } \\
\text { Files, SAAS, SAP, etc. }\end{array}$ & $\begin{array}{l}\text { In Tableau, data loading } \\
\text { is implemented by } \\
\text { connecting to Data } \\
\text { Stores, Databases, files, } \\
\text { etc. }\end{array}$ & $\begin{array}{l}\text { Power BI is integrated } \\
\text { with other products } \\
\text { from Microsoft (Office } \\
365 \text {, etc.), with R and } \\
\text { Python. It is possible to } \\
\text { connect almost any data } \\
\text { source (streaming data, } \\
\text { cloud services, Excel } \\
\text { work-books, SQL Server } \\
\text { databases, MySQL, MS } \\
\text { Asure, and other third- } \\
\text { party applications) and } \\
\text { combine them. Power } \\
\text { BI has a simple API for } \\
\text { integrating into its own } \\
\text { applications. }\end{array}$ \\
\hline & $\begin{array}{l}\text { Supports } \quad \text { multiple } \\
\text { platforms } \\
\text { mobile). }\end{array}$ & $\begin{array}{l}\text { Work in Tableau is } \\
\text { carried out in the web } \\
\text { version. }\end{array}$ & $\begin{array}{l}\text { Power BI is easy to use } \\
\text { and has an intuitive } \\
\text { interface. Supports } \\
\text { multiple platforms (web, } \\
\text { desktop, and mobile). }\end{array}$ \\
\hline
\end{tabular}

\section{Materials and methods}

Today, at al-Farabi Kazakh National University (further - KazNU), the information infrastructure uses such information systems as self-developed systems (IS "UNIVER" - a system for automating the educational process, IS "Science" - a system of accounting for 
Development of the information and analytical ...

research activities, system of indicative planning and rating based on IS "UNIVER" [5]); electronic document management system "Directum"; accounting and personnel accounting systems ("1C: Enterprise 8.2"); time tracking system "Perco 2.0"; the system of statistical reporting of the contact center "VoIPTime Contact Center." |6 These information systems were integrated with the cloud platform Power BI to build an IAS within the KIS KazNU (fig. 1).

The work of the information and analytical system (IAS) is based on the application of knowledge about the organization of business processes of the university, methods, and models of working with data, data analysis and monitoring, data interpretation, so that IAS users have the opportunity to offer objective solutions to emerging issues, and make more objective management solutions.

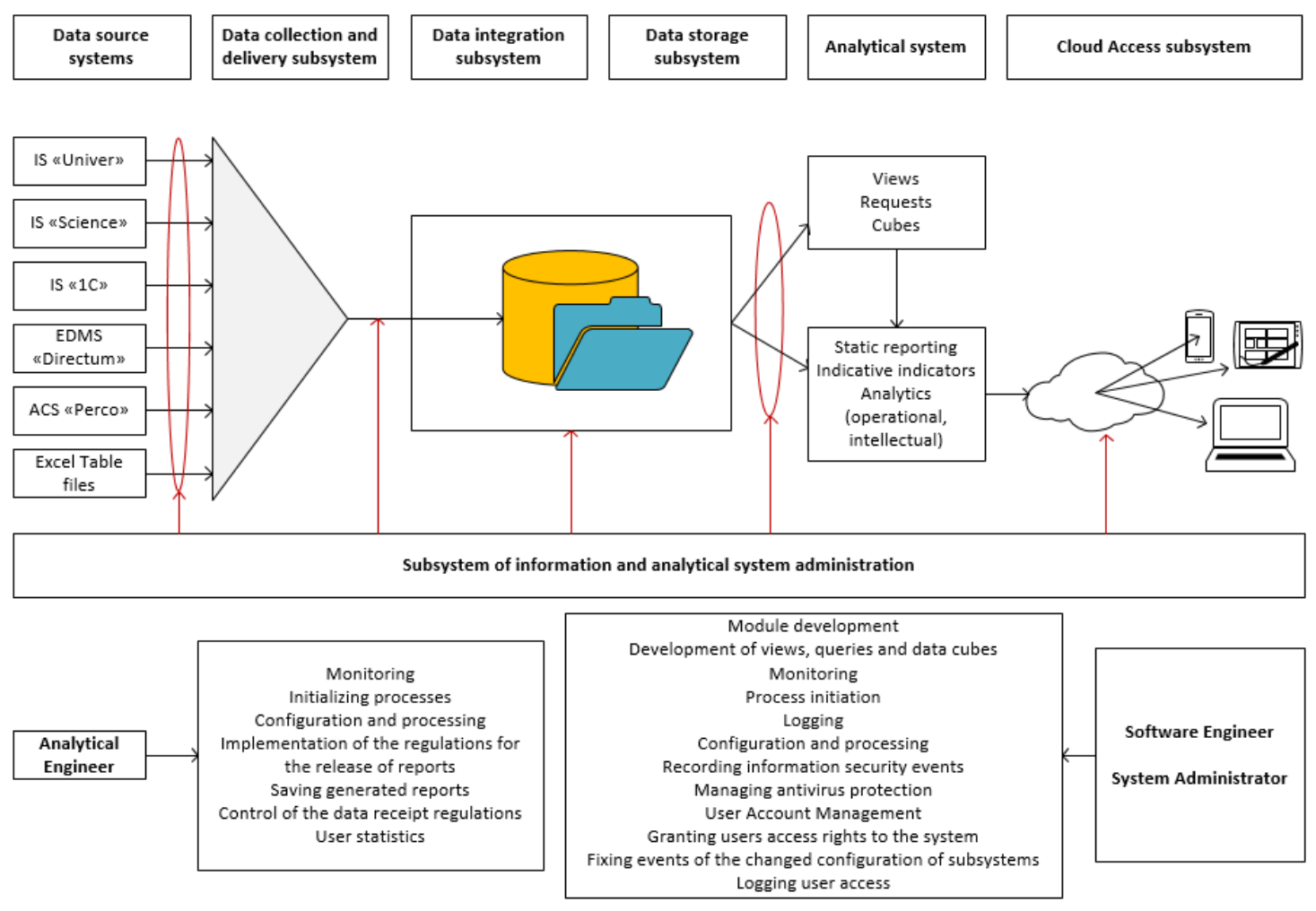

Figure 1: The architecture of IAS CIS of KazNU

The analysis of the statistical reporting of the corporate information system of KazNU showed that there are various categories of indicators at the university that are used in the formation of the reporting system. In this regard, the logic of the formation of analytical data was proposed, which easily inherits the hierarchical organization of data at the university (primary data, operational data, statistical indicators, statistical reports, indicative indicators, strategic indicators) and is easily programmed to build analytical indicators $|5|$. For the university leadership, there are clear benefits from the development and implementation of IAS in the university management loop, as a function: prompt response, operational monitoring, control of the University development strategy, reduction of labor costs for routine operations of automation of the university's statistical reporting. The result 
of using IAS tools is regulatory analytical reports focused on the needs of users of vari-ous categories, tools for interactive analysis of information, and rapid construction of reports by non-programmers using familiar concepts of the subject area.

\section{The architecture and data for IAS}

IAS implementation includes several essential stages: deployment of Microsoft SQL Server DBMS on a dedicated server/computer; building a data warehouse that receives information from various sources; Importing data into the Power BI business intelligence platform construction and visualization of reports; publishing a report to Power BI; installation of a gateway and automatic updates $[7]$.

For the implementation of analytical reporting, it is necessary to provide for an appropriate data architecture of the University's CIS (fig. 2), which should consist of a data warehouse (DD), a data lake (OD), and a data mart (serving layer) [8, 9].

Data Warehouse is a system that collects data from various database sources within the university, developed and designed to prepare reports and business analysis to support management decisions. HD represents detailed data, aggregated data, and metadata (technical and business metadata).

Data Lake is a repository that stores a vast amount of raw data in its original form (RAW format). In the data lake: each unit of data has value now or in the future; data is stored for as long as needed; data is transformed when the need arises; data is interpreted following research goals. The data lake has a flat architecture.

Data lakes include structured data from relational databases (rows and columns), semistructured data (CSV, log files, XML, JSON), unstructured data (emails, documents, pdf), and even binary data (video, audio, image files). The model of the data lake operation involves unloading data from a data source, preparing data, transforming and analyzing data, publishing data in data marts, and consuming data in the required reporting forms. When working with the objects of the data architecture of the corporate information system of the university, the important processes are data reception, data storage, data quality, data audit, data exploration, data discovery [10].

Data sources of ML and CD KIS KazNU are:

- educational process management systems (data and log files of the IPK "UNIVER" and IS "Moodle");

- accounting systems (IS Science, 1C: Enterprise 8.2, Perco, online telephony systems);

- electronic document management systems and electronic archives: EDMS "Directum";

- local documents: file storage IPK "UNIVER" and IS "Science";

- external sources: excel files.

Fig. 2 shows the standard data architecture of KIS KazNU, represented by the following levels:

- level of data resources: DB IS, corporate IS, users, data of log files;

- ETL level: level of extraction, transformation, and loading of data;

- data level: o CD: cloud, which integrates data from the CIS database; o data marts: grouped thematic dataset; o OD: cloud, into which the data of log files, video, audio data are uploaded: 
- the level of analytics - visual forms of statistical and analytical reporting (for educational, scientific, social, administrative, financial, etc.);

- access level for data mining: access at the level of analytical engineers and software engineers.

The collection of data into the university's information systems is carried out both in manual and automatic modes. IS "UNIVER" collects all categories of data on the educational process of the university: students, teachers, educational process.

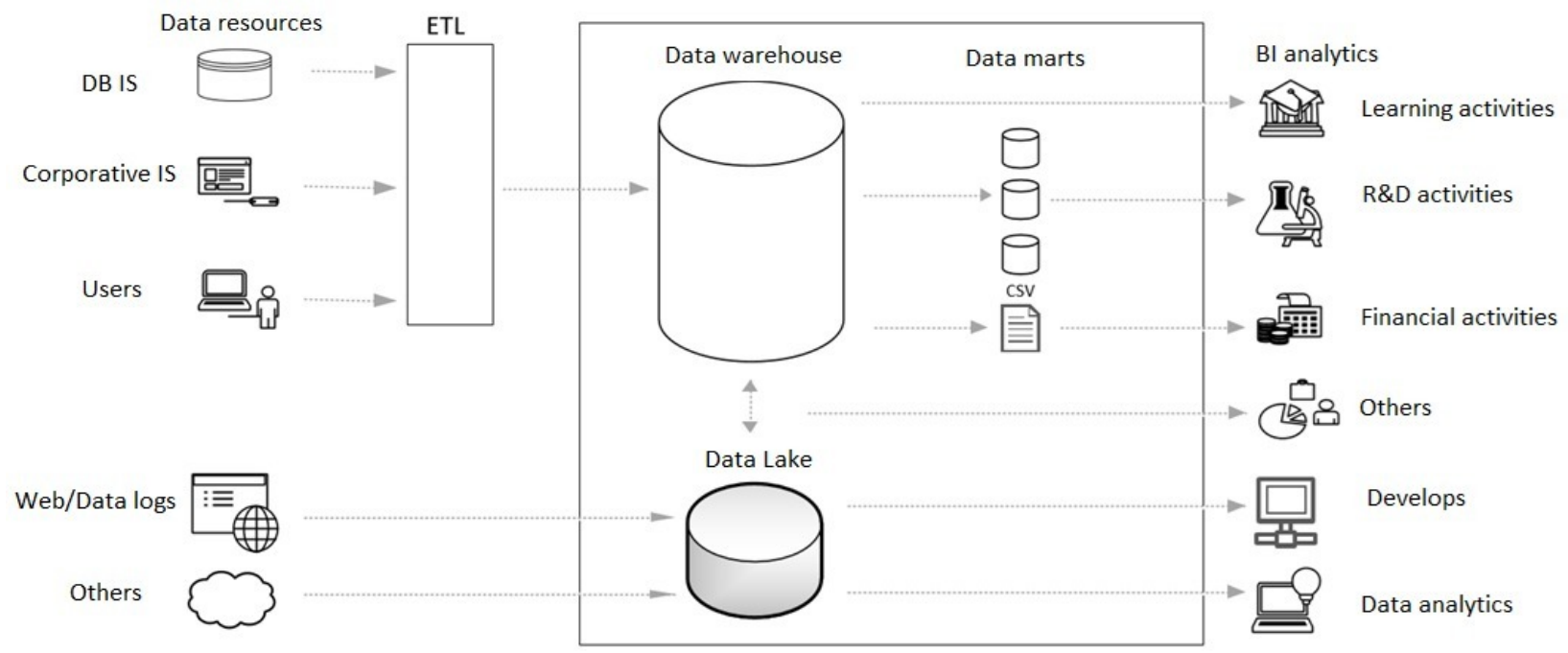

Figure 2: The standard architecture of CIS of KazNU

The following types of data are collected for students: personal data, citizenship, country, region of residence, faculty, specialty, department $(\mathrm{ru} / \mathrm{kz})$, stage of the study, language of instruction, course of study, a form of study (grant / paid), data on the results of UNT, etc.

On the educational process with the student: ID-group, the full name of the curatoradviser, name of the discipline by semester, the full name of the teacher of the discipline by semester, class schedule: semester, date, time, place, links to the online lesson; exam schedule: date, time, place, ID-admission to the exam, the format of the final exam, full name of those checking the student's examination data; discipline attendance data.

According to the student's progress: marks for foreign discipline controls, marks for MIDTERM by discipline, results of final exams in the discipline, GPA, the presence of arrears, data on retaking exams, data on non-attendance at the exam, the fact of violations during exams, etc.

According to the student's interaction with e-learning systems: the number of downloads of educational materials, the number of views and downloads of video recordings of online lectures, the number of visits online classes, the number of page views, etc.

According to the behavior of the student in the IPC "UNIVER": the number of visits to the system, the length of stay in the system, data on the visited web pages of the system, the most visited service/page, viewing the progress journal, viewing information about the teaching staff, the number of views/downloads of training materials, electronic resources, for 
a certain period, loading of completed tasks, data on passing tests and exams (duration of writing answers, grade, results of anti-plagiarism checks (in the case of a written exam)).

Personal data on the teaching staff of the university is extracted from the accounting and personnel accounting system "1C: Enterprise", which is the primary source of data on university employees: personal data, citizenship, country, region of residence, address, work experience, the start date of employment, date of adoption, date dismissals, data on breaks (if any), diploma specialty, position, rate, academic degree, academic title, types of allowances, faculty, department.

Educational data on the teaching staff of the university in the IPK "UNIVER": Name of the discipline, credits, language of instruction, specialty, semester, midterm points for the discipline, MIDTERM scores for the discipline, exam scores for the discipline, data based on the results of the questionnaire (teacher through the eyes of students, teacher through the eyes of colleagues, the quality of educational materials in the context of the semester, date), data on the loaded educational and methodological complexes of disciplines (name, type of EMCD, download date, update frequency, amount of material, data on the correspondence of the material to the discipline), ID-students in the discipline, schedule disciplines, data on the log of visits (date, discipline, date of entry of data on attendance, points for the lesson).

Ranking indicators for the teaching staff of the university in the IPK "UNIVER": name, department of the employee, units, directions, year, indicators, code, name, result of the indicative indicator of this employee, questionnaire plan, fact of questionnaires, monitoring plan, goal achievement index.

The IS "Science" collects data on the research activities of the teaching staff and students of the university. Including scientific articles, publications, and books: author, title, the language of publication, year of publication, title, and rating of the scientific publication, type of publication, number of pages.

The data collection into the Perco time attendance system occurs automatically from the 1C: Enterprise IS name, faculty, department, division, identification code, student training period, and information received from devices (turnstiles) using Perco software: arrival time, departure time, date.

For storage in CD, OD, and display in the Data Showcase, it is necessary to carry out preprocessing procedures, which are carried out using SQL queries.

The primary processing procedures in the SQL query language are queries to retrieve data from the primary source of the data table; stored procedures for processing trigger operations for dynamic reports; presentation of data obtained from primary sources and

stored procedures for obtaining visual reports in which related data from different databases are synchronized.

\section{The program realization of IAS}

After collecting data, the process of extracting, transforming, and loading data is carried out to generate analytical reports on all types of university activities.

Data for analytical research is retrieved by Power BI business intelligence software by connecting to the IAS data warehouse. After the data is retrieved, the relationship between the tables is configured, if necessary. 
At the data transformation stage, the following operations are performed: the transformation of the data structure; aggregation of data; translation of values; combining data from multiple sources; changing the data type; creation of metrics; other.

The extracted and transformed data is a source of information for generating analytical re-ports in visual and tabular forms.

In addition to importing and transforming data, an equally important stage of work in Power BI is building analytical reports. Visualization allows you to compare data visually, make convenient accents on essential things and carry out a lot of research in different sections.

When building an interactive reporting form (data mart), you need to understand the answers to basic questions: why is this report?, for whom is this report?, what data can be visualized in this report?.

Power BI offers an extensive range of visualization elements, allowing you to build reports of almost any complexity. In addition to the basic well-known histograms and graphs, there are a wide variety of charts (essential and funnel-shaped, waterfall and indicator, combined and bubble, and others), matrices, maps (base and cartograms), slices, plane trees, as well as images and simple cards with one number. The importance of a large number of elements in the analysis of learning activities cannot be overestimated. An example of the report visualization is shown in fig. 3. The developed visual representations of the university's statistical reporting represent more than half of all forms of the university's statistical automation system IS "Univer 2.0".

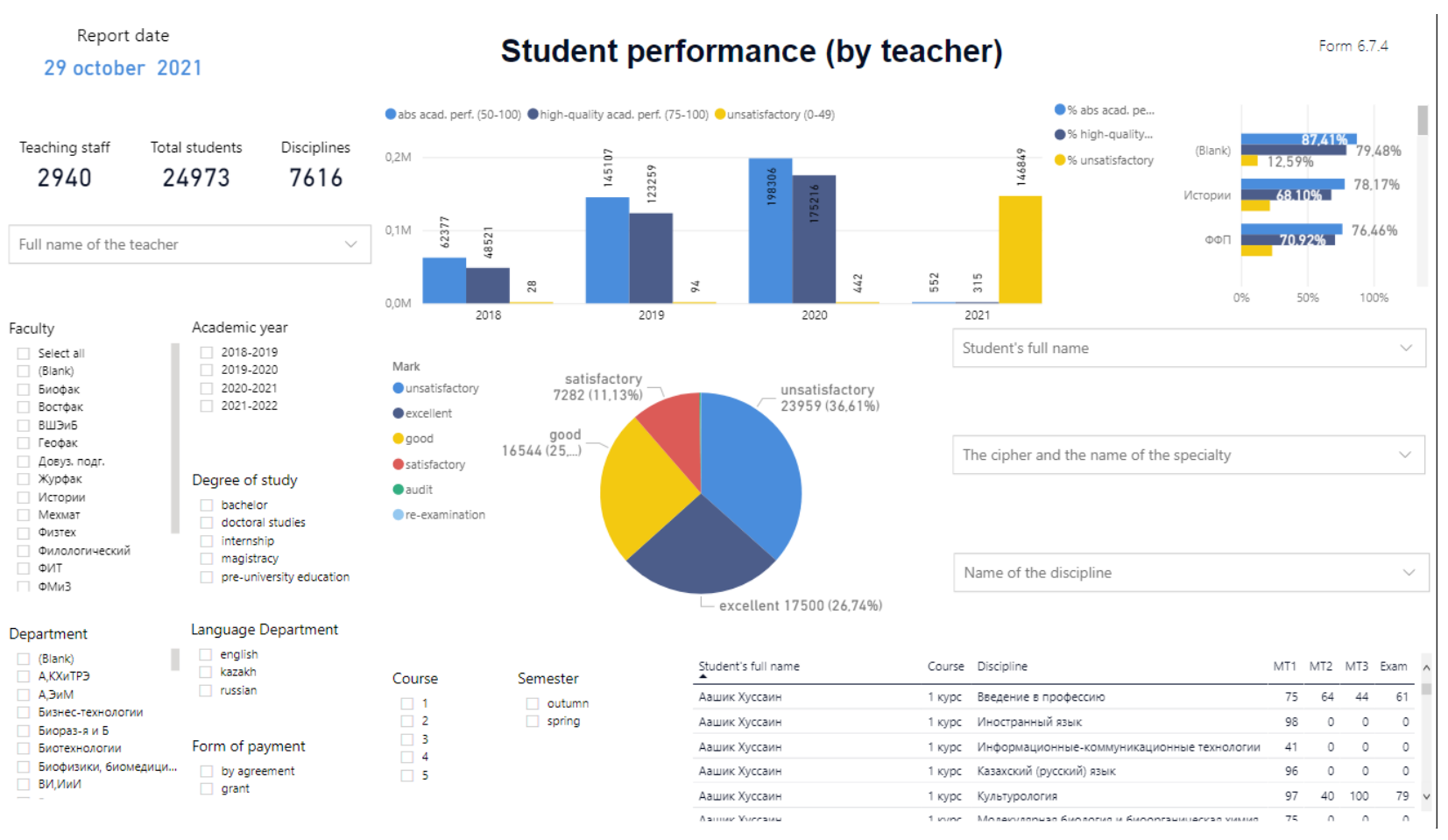

Figure 3: The visualization of reports on the educational activity of KazNU

The analytical report generated in the business intelligence software is loaded into the cloud version of the software, with the ability to configure access to reading and editing the report. 
By the role-based policy of the KIS KazNU, the following roles of the IAS are provided, such as system administrator that has full rights to fully manage data, services, and system settings, users of CIS systems, such as dean, deputy dean, teacher, curator-adviser, DAV specialist, CSO employee, accountant, management. Students have rights with a limited scope of data visibility ac-cording to their role in the university's organizational structure. Analytical engineers and Software Engineer have full rights to work with data at the data warehouse level, data lake, without the right to delete. The system administrator has full rights to configure and manage the DBMS, data warehouse, and data lake by system parameters.

IAS users, such as the rector, vice-rectors, department directors, deans, deputy deans, CSO employees, heads of structural divisions, have the right to view analytical reports following their type of activity in the organizational structure of the university.

Access to information systems and the information and analytical system can be provided temporarily and permanently.

The data from the IAS are used for generating statistical reports on the educational, scientific, social, administrative, and financial activities of the university; data analysis and visualization; identifying patterns in data using data mining methods; predicting student performance; providing feedback to support the work of teaching staff; providing guidance to students; identifying unwanted student behavior; optimization and modernization of the educational content of the training course; statistical analysis to investigate the nature of the data.

\section{Results and discussion}

Information and analytical system have been developed, which is integrated into the outline of the corporate information system of KazNU; instructions have been developed for programmers to create a system.

In the context of the digital transformation of the university, the development of digitalization processes, it is necessary to introduce a culture of data management: collection, analysis, communication, identification of bottlenecks, understanding, application, tools, management strategy, focus on results. This will allow you to assess the value of IT technologies and ensure effective decision-making. However, there is a problem here - data management is still under development in many institutions. Therefore, it is necessary to start with simple tasks and make efforts to build the entire data management model of the educational process, automate the visual presentation of statistical reporting, and bring it into an analytical presentation.

Thus, at the Kazakh National University, work is underway to develop a data management strategy based on methods for determining how data is collected, stored, processed and used for various tasks of the development of the education system and decision-making, which makes it possible to build an information and analytical system that integrates and accumulates disparate corporate data. Information systems provide an analysis of an educational organization's scientific and educational activities in the main areas of development, which are formalized as the quality of educational services, research potential, innovation orientation, information, and technical and technological infrastructure. 


\section{Conclusion}

This article discusses an approach to the design and implementation of IAS on the cloudbased business analysis platform Microsoft Power BI, which integrates all the disparate data of corporate information systems of the university and transactional data sources. The analysis of data types used as a data source for analytical reporting is carried out, the architecture of the IAS is presented, the logic of data extraction and transformation is described, the role-based access model is presented, and the form of visual reporting is presented.

The approach used by the authors in the article to apply research with data in the education system on the example of the Kazakh National University named after al-Farabi can be scaled to any organization that has a corporate information system, consisting of its own and local developments of information systems and who want to conduct a deeper analysis of the organization's activities to make the right strategic decisions.

The economic effect of the introduction of such a system is early identification of "bottlenecks" in the organization of the education system, prompt decision-making; in a systematic and complex analysis of the main business processes of the organization of education, through building a data map and visualizing all statistical reports, using data mining algorithms, thereby contributing to the digital transformation of the main business processes of the education system.

\section{References}

[1] Publication "Comparison of the top 4 popular BI platforms"[Electronic resource], - Access mode: https://habr.com/ru/company/newprolab/blog/349186/.

[2] Publication "Comparison of BI systems"[Electronic resource], - Access mode: https://habr.com/ru/post/438648/.

[3] The official website of the Power BI software [Electronic resource], - Access mode: https://powerbi.microsoft.com/.

[4] Publication "2021 Gartner Magic Quadrant for Analytics and Business Intelligence Platforms"[Electronic resource], Access mode: https://info.microsoft.com/ww-Landing-2021-Gartner-MQ-for-Analytics-and-Business-Intelligence-PowerBI.html? LCID $=E N-U S$.

[5] Mamykova Zh.D., Mutanov G.M., Bobrov L.K., Gusev Y.B. Indicative planning and rating assessments in strategic management of the university: information support system // Bulletin of NGUEU: heading society and economy: problems of development. - Novosibirsk: Publishing house "NGUEU 2013. - № 1. - C. 10 - 21 (impact factor of the RSCI 0,254).

[6] Mamykova Zh.D., Mutanov G.M., Bobrov L.K. Electronic campus in a socially oriented model of Smart society // Ideas and ideals: scientific journal. - Novosibirsk: Publishing house "NGUEU 2013. - Volume 2.- № 2. - C. (impact factor of the RSCI 0,053).

[7] Kumargazhanova S., Uvaliyeva I., Baklanov A., Zhomartkyzy G., Mamykova Zh., Ipalakova M., Gyorgy G. Development of the Information and Analytical System in the Control of Management of University Scientific and Educational Activities // Journal of Applied Sciences «Acta Polytechnica Nungarica» // ISSN 1785-8860 (IF for 2018: 1.286)// DOI: 10.12700 / APH.15.4.2018.4.2 // https://uni-obuda.hu/journal/Saule_Indira_Aleksander_Gulnaz_Zhanl_Madina_Gyorok_83.pdf.

[8] Bolatkhan M., Mamykova Zh.D., Kopnova O.L., Kistaubayev E.B., Karyukin V.I., Rabat Sh.Zh., Sundetova Zh. Report "Applied research of data management in the education system for decision-making (on the example of a university)" 2020.

[9] Mamykova Zh.D., Mutanov G.M., Bobrov L.K. IT infrastructure of the university as a platform for the development of information technologies // Bulletin of the NSUEU. - 2013. - № 4. - C. 276-287. 
[10] Abdrakhmanova, M., Mutanov, G., Mamykova, Z., Tukeyev, U. Agents interaction and queueing system model of real time control of students service center load balancing // Lecture Notes in Computer Science (including subseries Lecture Notes in Artificial Intelligence and Lecture Notes in Bioinformatics). Volume 11055 LNAI, 2018, Pages 349-359. (CiteScore - 1.9, quartile 1 (percentile 91), link to the publication - https://www.scopus.com/record/display.uri?eid=2-s2.0-85053192399E6origin=resultslistEsort=plf$f \in s r c=s \in s i d=6 b 052 d 7 b 5 f b e a a 90 a f b f a b 8 d b b c 6 d 3 d 9 \& s o t=a u t d o c s \& s d t=a u t d o c s \& s l=17 \& s=A U$ -

ID\%286506682964\%298relpos $=4$ EciteCnt $=4$ Esearch Term $=$. 